After the second day the bird expanded its territory and became even more vocal. It moved through the other groves and among the private residences where it climbed over the vines and trellises, singing and affording almost arm's length views of its beautiful coloring. All day long it could be seen flitting about, examining minutely every part of the territory from the ground to the top of the tallest trees: flower beds, vines, trellises, ledges, telephone poles, telephone wires.

And all day long it would sing its unmusical but pleasing and distinctive songs. What we might call its No. 1 song: The one it rendered the most-was a dry trill risingin pitch and increasing in tempo, then ending very suddenly in a very emphatic and buzzy note. It might be described as follows: Cheweechewee - chi - chi - chi - chi - chi zh. Song No. 2 was rendered sparingly: only once did I hear it used more than a dozen times in succession. This song was usually three buzzy notes followed by the same dry trill as in song No. 1. Song No. 2 might, be described as follows: Zwee-zweechi - chi - chi - chi - chi.

It is difficult to imagine what brought this eastern warbler so far out of its normal range. It is a new addition to the Saskatchewan check list but on the present evidence it must be placed in the accidental category. No female was seen and nesting did not occur in this area. For eight days this beautiful male Parula Warbler graced our premises. We heard it last at 8:30 p.m. on June 7, 1956.

\title{
Say's Phoebe in Saskatchewan
}

\author{
By FRANK H. BRAZIER, Regina
}

According to P. A. Taverner (Birds of Canada, 1934) Say's Phoebe (Sayornis saya) is found in "Western North America from central Alaska and Mackenzie south to New Mexico. In Canada, east to southwestern Manitoba, where it seems to be a comparatively recent arrival." This is a bird of the arid areas of the West; hot, dry gulches, desolate mountain sides, as well as barns and outbuildings are typical haunts. One would expect it to be generally distributed throughout southern Saskatchewan prairies, but so far as I can find there is no published record of the bird's occurrence in Saskatchewan farther east than Regina, although southwestern $\mathrm{M}$ a nito b a (Turtle Mountains) is within its range (Taverner, op. cit.).

Say's Phoebe is a $7 \frac{1}{2}$ inch flycatcher, with grey-brown back, slightly darker head, and dark brick or rusty ochre underparts. Look for a bird a little larger than a House Sparrow, with a black tail and yellowish or reddish belly, grey breast, and the typical habits of a flycatcher. It occurs quite commonly in Regina, and seems to be increasing here. Between the years 1947-1953 I recollect only the one pair which nested annually in our neighborhood. One arrived each April 17th for
1953, 1954 and 1955 but as it was cold and snowy that date in 1956 it did not show up until noon, April 19. In 1955 I observed 10 birds in Regina including the pair with its four young in the backyard. This year (1956) I have seen 15 individuals in widely separated areas in the south half of Regina, including the home pair with three young. Mrs. H. F. Tempel reports a pair nesting for six years in the porch at 17 Ingersoll Crescent, Regina, in spite of the four busy boys of the house. Mrs. Tempel also reports a pair nesting in the 2600 block Atkinson Street. These birds avoid the trees and rest on posts, wires or house tops.

In a recent survey $\mathrm{Mr}$. and Mrs. Harry Flock (Regina), Mr. P. Laurence Beckie (Bladworth), Mr. Steve Mann (Skull Creek), and Mr. John Walker (Moose Jaw), all record Sayornis saya. Mr. Mann adds that while the bird still breeds commonly in his area, its numbers have gone down in recent years. Mr. Frank Baines (Saltcoats), Mrs. Ann Olson (Big River), Mr. Stuart Francis (Torch River), Mr. Maurice Street (Nipawin), Messrs. Ronald a n d Donald Hooper (Somme), Mr. William Niven (Sheho), Messrs. A. Wilson and W. Jasper (Struan), and W. Yanchinski (Naicam) do not re- 
port Sayornis saya in their respective areas. These negative reports are to be expected as the latter eight points are in park and forest areas.

Mr. John Walker, in his report, adds an exciting observation: "Say's Phoebe has always been prevalent at North Portal." This is the most easterly report of a population of Say's Phoebe in Saskatchewan.

Mr. E. Manley Callin; of Fort San, writes: "My 30 years of bird watching include: 4 years at Punnichy, 4 years at Kipling, 13 years at Fort Qu'Appelle and you might say 30 years at Whitewood as I have always covered that territory to some extent even when residing elsewhere - and I do not have one record of this species." Mr. J. F. Roy (Saskatoon) advises that Say's Phoebe nests at the railway stations and houses oi nearly every village of the Beechy line, the birds occurring regularly as far north as Hanley. Lucky Lake had nine breeding pairs in 1940. Mr. Ed Brooman. (Prince Albert) gives an interesting report of the occurrence of Say's Phoebe at Round Lake (west of Prince Albert).

I have examined the reports of the Hooper Brothers (Birds of the Somme District), Houston (Birds of the Yorkton District), Street (Birds of Nipawin), Todd (Birds of Southern Saskatchewan), and the two reports of Godfrey (Birds of the Cypress Hills and Flotten Lake Regions) and Mitchell (Catalogue of the Birds of Saskatchewan). Say's Phoebe were not mentioned in the reports from the forest belt [Hooper, Houston, Street, Godfrey (Flotten Lake)] nor was it seen by Todd who collected with Lloyd in 1932 in the region surrounding Davidson, Last Mountain Lake east of Imperial and Elbow, Quill Lake, Touchwood Hills, and Quinn's Lake. Godfrey observed Say's Phoebe only three times in the Cypress Hills and reported it uncommon. Mitchell states that Say's Phoebe is a fairly common summer visitant in the southern part of the prairie region, "found breeding mostly in Cypress Hills district, more sparingly eastward to Regina district." Evidently Mitchell had no record of anything east of Regina.

The records of the Saskatchewan Museum of Natural History contain. the following: female skin, Regina; nest and eggs, Sandfly Lake; 5 eggs,
Bigstick Lake; mounted female, Regina; nest and eggs, Ravenscrag; mounted male, Old Wives Lake; and male skin, Cypress Hills. The first two records were taken by Buchanan and the last five by Mitchell. These items date between 1913 and 1921. In addition there are eleven other recorded occurrences in the Museum's books made by Bard and Mitchell from Regina, Eastend, Ravenscrag, Val Marie and Harptree. I am indebted to Dr. R. W. Nero of the Museum staff for the foregoing information as well as for a note on this bird by Wood (Preliminary Survey of the Bird Life of North Dakota, 1923)" ... found only in the extreme west portions of North Dakota." This accords well with our own records.

The Say's Phoebe seems to be the replacement species for the Eastern Phoebe in western North America. During spring migration we see both birds for a short time in Regina, but the Eastern Phoebe moves on to forested areas. Readers are asked to tell us if they know of the two birds nesting in the same area. We are interested in any report of the distribution or abundance of the Say's Phoebe. We are especially interested in receiving reports from the area covered by Todd north-west of Regina and in the area east of Regina to the Manitoba border. Please report any sightings to the Editor, with description and other particulars, so that the published record may be complete.

Dr. G. F. Ledingham and Mr. J. H. Hudson noted a nesting of the Say's Phoebe at Lodge Creek (22-1-29W3) on May 31,1956 , in a dry gully typical of the natural habitat. Such habitat, bare of cover, would be more open to predation than nests set high under the eaves of houses such as are seen in Regina. Phoebes, like other birds which nest in company with man, find increasea nesting sites and more food around our homes. Under these conditions we would expect Say's Phoebe to prosper as have the Robin and the House Sparrow. During the last two years we have enjoyed the sight of 4 and 3 bob-tailed phoebes sitting in a row on the fence being fed by attentive parents. Look for these birds, and listen for the plaintive "pee-urr"; I'm sure you'll enjoy their company. 